\title{
Teacher Perceptions and Practices in an English Conversation Lounge
}

\section{Adam Garnica}

Tokyo International University

\author{
Ramon Mislang \\ Hitotsubashi University
}

\section{Reference Data}

Garnica, A., \& Mislang, R. (2021). Teacher perceptions and practices in an English conversation lounge. In P. Clements, R. Derrah, \& P. Ferguson (Eds.), Communities of teachers \& learners. JALT. https://doi.org/10.37546/JALTPCP2020-28

This research focused on examining how language was being used in a mid-sized private Japanese university's English conversation lounge. Data on distribution and length of turns as well as quantity and quality of utterances were recorded through surveys with students and instructors as well as interviews with instructors. Data was also collected to investigate student perceptions, attitudes, and motivations for conversation practice with native English speakers. The results of reported talk time from students and teachers attending the lounge demonstrate a mismatch between the expectations of stakeholders and the reality of conversation practices beyond the classroom. The implications of the findings can help inform the development of, and training for, similar English conversation lounge areas or social learning spaces at other universities.

本研究では日本の中規模の私立大学構内に設けられた英会話ラウンジにおいてどのように言語が使われているかに焦点 を合わせて考察を行った。研究方法としては、学生と教員を対象にしたアンケート調査と、教員へのインタビュ一を行い、てれ らを通して、会話の配分や受け答えの長さ、また発話の量と質を記録した。調査では、学生が感じたことや態度、そして英語の ネイティブスピーカーと会話を練習するモチベーションが何かについてデータを収集し、分析した。結果として、関係者の期待 と教室外での会話練習の現実との間に粗蹬があることが判明した。本研究で得られた知見は、他の英会話ラウンジや他大学 構内の社会学習スペースの開発や研修などに活用できると考えられる xtending learning opportunities beyond the classroom is a goal for many language programs. While some programs have language labs and self-access libraries, other programs have social learning spaces or English conversation lounges. Tokyo International University (TIU) combines elements of these learning opportunities through a designated multipurpose language center called the English Plaza (EP). The EP falls under the purview and responsibility of the Global Teaching Institute (GTI), which is in charge of compulsory English-language courses at the university. Two goals of the EP are to create an environment that fosters world-class communication skills and provides opportunities for student interaction.

First- and second-year students in the School of Language and Communication at TIU are required to visit the EP every week. Specifically, students attending listening and speaking courses must visit the EP and register for one conversation session at the lounge each week. The lounge is a space within the EP where a language teacher and up to three students can engage in a 15-minute conversation session. For third- and fourthyear students, attending a lounge is not compulsory. However, certain third- and fourthyear electives may highly encourage students to attend lounge sessions.

Lounge observations and conversation transcripts from a pilot research study conducted by the authors in 2019 created initial interest in exploring lounge practices (see Garnica \& Mislang, 2020). Data from the pilot study revealed a number of concerns. First, activities such as interviews, worksheets, and games conducted at the lounge appeared to create minimal speaking opportunities for students. Second, lounge activities did not encourage students at the same lounge session to interact with each other. As a result, activities encouraged isolated monologues instead of increased interaction between all interlocutors. It is fair to say that part of the reason interlocutors may be inhibited or unable to interact smoothly in an English conversation is connected to differences between the oral communication styles of English and Japanese speakers. Language proficiency may be another factor that contributes to underperformance in 
English conversations. However, the researchers were interested in exploring other variables that might affect performance in conversations at the lounge.

In this study, the researchers explored three questions:

- What do students and instructors perceive as the purpose of conversations at the lounge?

- How do instructors prepare students for conversations at the lounge?

- What are the expectations of students and teachers at the lounge?

\section{Literature Review}

Research in the area of English conversation lounges is sparse, as noted by Kasper and Kim (2015). Their recommendations for further research inspired this project, with the researchers stating that future studies should "expand the database not only quantitatively but also qualitatively" (p. 405). By starting with a questionnaire, the researchers are hoping to add some much-needed qualitative and quantitative data to the conversation about English lounges via a series of open-ended discussion questions students were asked to complete, in addition to general multiple-choice questions (for an example of selected survey questions, see Appendix A). There is currently a lot of interest in self-access language learning (SALL), with a lot of research focusing on SALL Centers but not on language lounges, which appear to embrace many aspects of SALL. There are many concepts that educators can borrow from SALL research to apply specifically to language conversation-for-learning, but the researchers desire to expand the body of research for their specific context.

Research on teacher attitudes and approaches to evaluation in this area is even more difficult to come by. Most research focuses on instructor's attitudes towards SALL and autonomy (Wichayathian \& Reinders, 2018) or perceptions and issues concerning assessment of self-directed learning (SDL) and SALL (Lau, 2018; Reinders \& Lazaro, 2008). While SDL and SALL are sometimes used synonymously because the primary aim of both approaches is to foster sustained independent learning, SALL actually helps facilitate SDL by helping students discover the intrinsic value of making choices in their learning in regard to language learning. There is also minimal research done on student perceptions (Cheng \& Lee, 2018; Cheng \& Lin, 2010) that can be called upon to help inform the types of questions the researchers ask instructors, but overall, we are attempting to pioneer something that has not yet been widely published.

In terms of what was included on the survey, the researchers wanted to see how an instructor's pedagogical approaches prepared students for the lounge and how their time in the lounge was utilized to reinforce concepts learned in their courses. When discussing pedagogical implications for SALL, Lau (2018) suggested that there be opportunities for students to share their SALL experiences in class, allowing them a chance for metacognitive awareness raising and engagement in sharing their strategies for approaching learning. Similarly, Cheng and Lin (2010) noted that students struggle with completing such SALL activities outside of the classroom and that they would benefit from metacognitive discussions about their learning experiences in class. This idea is reflected in questions where the researchers asked instructors what follow-up activities they did with students after they visited a lounge and whether or not they had students discuss their learning strategies in class. Preparing students for their lounge experience ties into how the literature speaks about preparing for SALL.

The survey included questions about training, the respondents' understanding of the purpose of the lounge, and how to prepare students to participate in the lounge. The premise for these questions comes from Lau's (2018) suggestion that new teachers be given SALL training, focusing on the rationale for its inclusion and how to better integrate it into their courses. Since lounge visits are a required grade for all first-and second-year speaking and listening courses within the GTI, they are already integrated into the curriculum. Additionally, Cheng and Lee (2018) found that continuous teacher or advisor intervention, check-ins, and guidance throughout the term contributed to more successful results in SALL situations. Since these practices can contribute to student success, the researchers wanted to measure their usage among GTI instructors. The researchers wanted to see how instructors were prepared, or how they would want to be prepared, to better integrate students' lounge participation into their pedagogical practices with the curriculum as well.

The researchers also wanted some of the questions to mirror those they might ask students, as many of these ideas can bear valuable insights into lounge practices, regardless of whether they are from students or teachers. For example, Brookfield (2009) noted that in self-reported data, students tend to overestimate their abilities and participation, leading to a mismatch in what students perceive is happening versus what may actually be happening. Asking this can help us examine if instructors are falling into the same pitfalls as the students in regards to participation time in each session. Similarly, Lau (2018) noted that the lack of insight from instructors creates an imbalance in the literature, as the researchers need teacher perspectives to get a more complete picture of what happens in these interactions. In past research, the researchers have collected transcripts of teacher-student interactions in the EP and have noticed some interesting data in terms of how often students are interacting with instructors and the 
way in which they are doing so (Garnica \& Mislang, 2020). The researchers hope that by collecting this data on perception, they can expand upon these survey results with transcripts of actual conversations to allow us a more complete understanding of the dynamics involved in the interactions at the lounge in the future.

\section{Participants}

A total of 144 participants participated in this study. Twenty-eight of the participants were international language instructors from the United Kingdom, Sweden, Belgium, and the United States, with a majority (24) being from the United States. These teachers were chosen to participate in the study because they are global teaching fellows (GTF) who work in theTIU's GTI. As part of their work requirements, instructors are expected to do EP duty, which consists of two 90-minute sessions in academic advising (assistance for students with academic questions) and/or the lounge (conversation practice between a GTF and students). All instructors have obtained a minimum of a master's degree in TESOL, applied linguistics, or a related field. Teachers' experience varies from recent graduates to those who have been in the language teaching profession for ten or more years.

The remaining 116 participants were Japanese students enrolled in the School of Language and Communication. Approximately 65 first- and second-year students participated in this study. The remaining 51 participants were third- and fourthyear students. Students' language proficiency ranged from A1 to B2 on the Common European Framework of Reference (CEFR). These students were chosen to participate in the study because all of them had experiences with participating in conversations at the EP lounge. All students and teachers gave their informed consent and agreed to have their data collected and used for this study. The project was also approved by the university's institutional review board.

\section{Methods}

Tools

For data collection, the researchers developed a survey (Appendix A) that asked student participants about their interactions in the lounge, and collected additional information such as their year of study, whether or not they had compulsory courses, and whether or not any of their current courses required visits to the lounge. Depending on their answers, the survey would prompt the students with different questions that more closely aligned to their year of study and their enrollment in compulsory courses. This survey was forwarded to language instructors involved in the facilitation process of the lounge sessions who could then present it to students as an extra out-of-class activity for them to complete.

To collect data from instructors, a modified survey (Appendix B) was created. Instructors were asked about their perceptions of student participation, their own participation, and their understanding of the purpose of the lounge. The researchers sent out the form to their peers, requesting volunteers from the 51 instructors at the university, and 28 responded to the survey.

After the responses were collected, follow-up interviews were scheduled with volunteers (8 in total), allowing the researchers to have them expand on certain ideas that were touched upon in the survey, such as how they structure a 15-minute session at the lounge, how specifically they invite or encourage students to speak, and what they believe to be the ideal time allotment for student production in a single session. The sessions were recorded and notes taken on their answers and compiled into a supporting document.

\section{Data Analysis and Results}

The data from the surveys were analyzed and open-ended questions were compiled and compared to the qualitative responses from participants to allow for extra context and reasoning behind why certain answers were given. Interviews from instructors were likewise compared to the qualitative answers from the survey to allow for more context to be given to the numerical answers.

To address the first research question, the researchers asked teachers and students about their perceptions of the purpose of the lounge. The researchers asked students specifically which of the four skills (plus grammar and pronunciation) they wanted to practice most in the lounge. The researchers also asked instructors what they felt should be practiced by students. In their responses, $85.3 \%$ of students stated that they wanted to practice speaking with the teachers in their lounge session. The second highest was grammar, with $6.7 \%$ of responses. Only $4.0 \%$ of students said that they wanted to practice listening with the teachers in the lounge. This data suggests that students wanted to spend more time actively producing language versus passively absorbing it. Comparing what they wanted to practice with what they perceived as practicing, a clear gap in expectations was present. Some factors were in play that were preventing students from speaking as much as they would like. These factors might have included an uneven distribution of talk time, lack of focus on the general purpose of the lounge, or more affective factors such as shyness or lack of confidence. 
The teachers' responses were likewise decisive, with $96.4 \%$ of teachers indicating that speaking should be the main skill students should be working on in a lounge visit, with only one respondent (3.6\%) indicating that it should be listening. The researchers then asked teachers what skills they actually believed students were practicing in the lounge, based on their own experiences leading a lounge session. Teachers responded with speaking at $53.6 \%$ and listening at $46.4 \%$. This split, with $96.4 \%$ wanting speaking to be the main skill worked on versus $53.6 \%$ of them saying this was the skill they see being worked on, suggests that students were not talking as much as teachers would like, and instead were listening more to the teacher. Both teachers and students expressed the desire for students to carry more of the conversation, but that desire didn't necessarily translate into what was happening in the lounge.

To further investigate the perceived disparity in teacher's perceptions of talk time, the researchers asked teachers and students to give estimates of how much time, in a typical 15-minute lounge session, was used by the teacher and the students for speaking or control of the floor. When asked in interviews what the ideal time distribution was in such a limited time frame, instructors generally agreed that half of the time should be controlled by the teacher and the other half by the students. From the student responses, $56.03 \%$ reported individual perceived contributions of speaking five minutes or more during a session, $32.61 \%$ speaking three to four minutes, and the remaining percentage speaking two minutes or less. In contrast, teachers when asked the same question gave more tempered responses, with $21.43 \%$ stating that students spoke for five or more minutes, $57.14 \%$ noting four minutes, and another $21.43 \%$ believing students spoke only one to two minutes. This data suggests that, based on perceptions only, teachers and students recognize that anywhere from $43 \%$ to $88 \%$ of students are not reaching the ideal amount of speaking time suggested by instructors during the conversation. If the students are not talking as much as everyone would like, it merits examining how much both groups perceived the teachers to be speaking.

As for the perception of how much time teachers spoke, both teachers and students reached a consensus: The teacher handles most of the conversation (Figure 1), with $78.57 \%$ of teachers and $75.86 \%$ of students stating that the teacher talks for five or more minutes during a 15-minute session. Responses from the teachers showed a $21 \%$ response of self-reported talk time for eight to ten minutes, and another $15 \%$ of teachers reported speaking nine or more minutes in the 15-minute session, meaning that $36 \%$ of teachers are not reporting that they are meeting the same ideal they set forth during the interviews. This, combined with the responses on student participation, suggest that both teachers and students were aware, to an extent, that both parties were not participating in the preferred manner, with teachers speaking too much and students speaking too little. The researchers then wanted to shift focus from perceptions to see what pedagogical support teachers were giving to students in their listening and speaking courses.

Figure 1

Perceptions of Teacher Talk Time

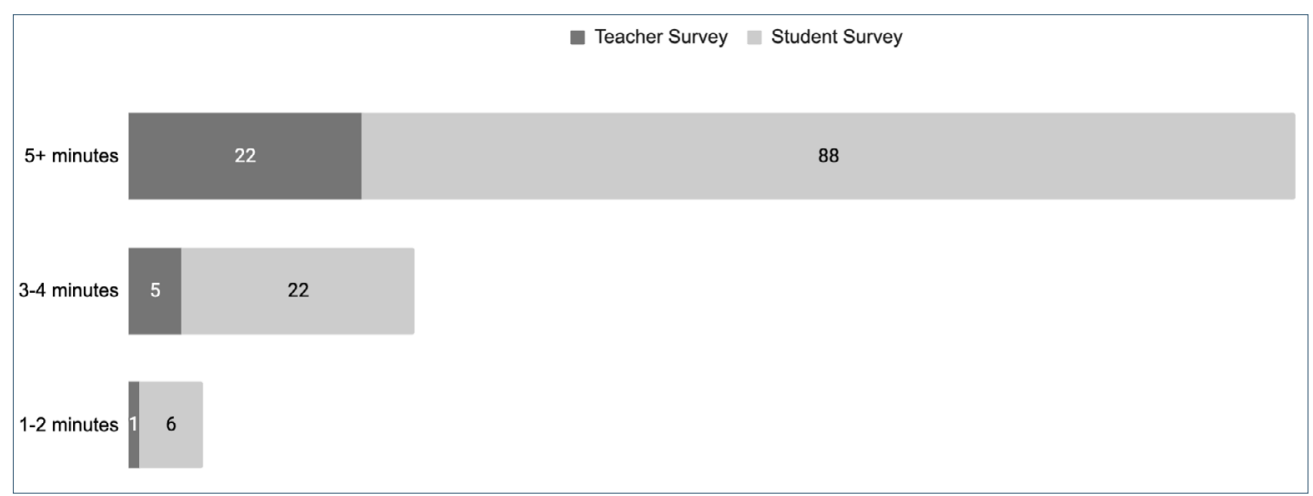

To address the second research question, the researchers asked teachers and students what they did to prepare themselves for their time at the lounge. Teachers were allowed to select multiple answers on the survey if they used multiple techniques or activities with their students. The most popular activities were preparing questions for the teacher (Table 1), selecting a topic before going to the lounge, and doing nothing to prepare. Additionally, the researchers asked if any specific time or attention was spent in class to help support students during their time in the lounge. From the responses, $71 \%$ of teachers did not allow time in class for students to discuss learning or conversation strategies that they used in the lounge. For follow-up activities, $89 \%$ of teachers followed up with student participation in the lounge by only checking their attendance via an online database or by a physical signature book, known as an English Plaza Passport. These numbers illustrate a lack of meaningful follow up by teachers to instruct their students on how to participate more effectively in the lounge. It also suggests a lack of time for reflection and metacognitive discourse on skills in English that teachers commonly have problems fostering outside of the classroom, both of which would set up students for more successful interactions in spoken discourse. 
Table 1

How Teachers Prepare Students to Participate in the English Lounge

\begin{tabular}{lcc}
\hline Response & Number of Responses & Percentage of Responses \\
\hline Review past sessions & 2 & $3.6 \%$ \\
Set language goals & 5 & $9.1 \%$ \\
Nothing & 9 & $16.4 \%$ \\
Teach conversation strategies & 11 & $20.0 \%$ \\
Select topics & 12 & $21.8 \%$ \\
Prepare questions & 16 & $29.1 \%$ \\
Total & 57 & $100 \%$ \\
\hline
\end{tabular}

Students were asked to focus on whether or not they prepared anything for their conversations, be they topics to discuss or questions to ask the teacher or other participants. An answer of "no" signified that they entered the conversation with nothing ready to begin or continue a conversation, while an answer of "yes" signified that they had one or all of the aforementioned materials, and an answer of "sometimes" signified that they prepared themselves inconsistently throughout the semester. Only $38.8 \%$ of students said they were prepared every session with a topic or a question to engage with in their conversation. "Sometimes" held the majority with $47.7 \%$ responding with this answer, while $13.8 \%$ responded with "no." The high percentage of "no" and "sometimes" responses show a lack of consistency with preparation on the part of the students, with nearly two-thirds not entering the lounge conversation with something ready to discuss. These responses, combined with the answers from teachers on the types of in-class support they give to students, may show a lack of preparedness being linked to a lack of guidance on how to be prepared and participate in a lounge session. If more instructional support were given, this could perhaps help to improve the overall quality of the conversations and have them meet the expectations for both students and teachers.

To address the final research question, the researchers also asked teachers and students what their expectations of the lounge were. The researchers asked both teachers and students what they perceived to be the purpose of the lounge: Did they view it as an informal learning space, a social space, a formal learning space, or something else entirely? The majority of students and teachers both believe that the purpose of the lounge is informal learning, with $73.2 \%$ and $78.6 \%$ of respective participants giving this response. The second most frequent opinion regarding the purpose of the lounge for teachers was that it was a social space $(7.1 \%)$ and that it was an academic, formal learning space for students (14.3\%). This data suggests that a majority of teachers and students did not associate their time in the lounge with any sort of formalized learning, which could give insights into previous responses in regards to why they may not have been preparing for the lounge as thoroughly as they may need.

\section{Discussion and Implications}

The results of reported talk time from students and teachers attending the lounge demonstrate a mismatch between the expectations of stakeholders and the reality of conversation practices beyond the classroom. As mentioned earlier, although the majority of students and teachers agree that informal speaking practice should be the primary goal of conversations at the lounge, data reveals that students are not getting enough speaking practice during their conversations with instructors. In fact, the data leads the researchers to believe that students engage in more listening practice than speaking practice. While language proficiency can affect the range of topics students can talk about for an extended amount of time and cultural norms such as silence and maintenance of conversation flow are factors in how turn-taking is negotiated in oral discourse (see Garnica \& Mislang, 2020), the power dynamics between interlocutors and the perceptions of the lounge may have a bigger impact on how conversation is realized at the lounge.

Some language programs may integrate instruction of conversation elements such as changing the topic, interrupting, and following up an utterance with a comment or question in course curriculum. However, attention towards the power dynamics between teachers and students is often neglected. Looking at some of the findings in the data analysis and results section, teachers want students to take more ownership of conversation in the lounge. However, students may defer to teachers to lead them in the lounge because teachers are seen as authoritative figures. Since teachers are seen as leaders in the classroom, they may also be perceived as leaders at the lounge, resulting in difficulty for students to be more active and engage in a more assertive role in conversations. This power dynamic may also extend to students of different years, influencing how first year students interact with third- and fourth-year students in the same lounge session. Given that the research takes place in Japan, and there is an established power dynamic of senpai (older or more senior classmate) and kohai (younger or more junior classmate), this may cause the first and second year students to show deference to their more senior peers. Further research into this power dynamic 
is suggested, as this may have a direct impact on how students perceive the lounge and guide how they participate in a session.

Students' and teachers' perceptions of the lounge may contribute to their expectations. For some programs, the lounge may be seen as an extension of the classroom. Data collected from this research project indicates that students and teachers did not see the lounge as a space for formalized learning and therefore not an extension of the classroom. Teachers with this perception of the lounge could potentially be less likely to structure activities and spend time in-class preparing students to participate in a more meaningful nature. If current and future students do not view it as formal, they may not see the value or purpose for preparing for these sessions, as casual conversation may not be connected to their ideas of what will help them improve their spoken language ability. This can create a cycle of unmet expectations. When students come unprepared consistently, teachers may encounter issues with running sessions in the lounge. These issues may also result in students becoming less interested in or discouraged to participate in the required lounge sessions.

\section{Conclusion}

To summarize, the researchers surveyed teachers and students to find out their perceptions about the lounge in order to better understand what they thought and felt about the requirement for participation in the lounge. There is a lack of literature on the subject, especially when it comes to perception. The researchers found that both teachers and students perceive a gap in participation, with teachers being the dominant force in most conversations, despite an expressed want from both parties for more student generated interaction in the discourse. Their perceptions of the lounge as an informal learning space may be causing them to create a negative feedback loop, in which the students are not prepared adequately to participate, and teachers are not supporting the students inside the classroom. The researchers recommend that more attention be placed within the classroom context in order to enrich the experience and achieve the goals of both students and teachers in this space.

Self-access environments and social learning spaces like the English lounge can add valuable opportunities for students to engage in learning beyond the classroom. Casual conversation on informal topics can make language learning fun and motivating. However, if the goals of spaces like the lounge are to foster world class communication skills, language acquisition, and SALL, more formalized classroom instruction may need to be integrated into the curriculum. In addition, more research on assessment of self-access environments and lounges needs to be undertaken to help connect language learning in the classroom with SALL resources outside of the classroom. Finally, teacher training is another aspect that deserves more inquiry as teachers may need more formalized, in-depth training to facilitate conversations equitably and effectively in unfamiliar cultural contexts.

\section{Bio Data}

Adam Garnica has worked for over ten years as an ESL/EFL educator in the United States, Thailand, South Korea, Mongolia, and Japan in K-12, university, and adult education contexts. He holds an MA TESOL from the Middlebury Institute of International Studies at Monterey and an MEd from Arizona State University. His research interests include collaborative learning, educational technology, and conversation analysis. <agarnica@tiu.ac.jp>

Ramon Mislang has worked for over ten years as an ESL/EFL educator in the United States, China, Hong Kong, and Japan in university and adult education contexts. He holds an MA TESOL degree from the Middlebury Institute of International Studies. His research interests include encouraging oral communication in the classroom, increasing awareness of behavioral norms in conversation, autonomous learning, and conversation analysis. <ramonsensei@gmail.com>

\section{References}

Brookfield, S. D. (2009). Self-directed learning. In R. Maclean \& D. Wilson (Eds.), International handbook of education for the changing world of work (pp. 2615-2627). Springer. http://doi. org/10.1007/978-1-4020-5281-1_172

Cheng, A., \& Lee, C. (2018). Factors affecting tertiary English learners' persistence in the self-directed language learning journey. System, 76, 170-182. https://doi.org/10.1016/j. system.2018.06.001

Cheng, H. F., \& Lin, N. C. (2010). Exploring students' perceptions of self-access English learning Procedia Social and Behavioral Sciences, 2, 2676-2680.

Garnica, A., \& Mislang, R. (2020). Using conversation cards to enhance turn-taking fluency. JALT PanSIG Journal 2019, 98-108.

Kasper, G., \& Kim, Y. (2015). Conversation-for-learning: Institutional talk beyond the classroom. In Markee, N. (Eds.) The handbook of classroom discourse and interaction (pp. 390-408). John Wiley \& Sons. 


\section{JALT2020}

COMMUNITIES OF

Lau, K. (2018). To be or not to be: Understanding university academic English teachers' perceptions of assessing self-directed learning. Innovations in Education and Teaching International, 55(2), 201-211. https://doi.org/10.1080/14703297.2017.1292942

Reinders, H., \& Lazaro, N. (2008). The assessment of self-access language learning: Practical challenges. Language Learning Journal, 36(1), 55-64. http://doi.org/10.1080/09571730801988439

Wichayathian, N., \& Reinders, H. (2018). A teacher's perspective on autonomy and self-access: From theory to perception to practice. Innovation in Language Learning and Teaching, 12(2), 89104. https://doi.org/10.1080/17501229.2015.1103245

\section{Appendix A}

\section{Student Survey}

The survey attached has been modified to fit the parameters of the journal. If readers would like access to the full survey, please contact either of the authors.

\section{General English Plaza Questions}

What is your main reason for going to English Plaza?

- Required work for a class

- To make new friends

- Extra English Practice

- To study

- To meet with my friends

- To play games

- To get a drink in the cafe

- Other:

What are other reasons you go to Plaza? Please check all that apply. Do not repeat your answer from the previous questions.

- Required work for a class

- To make new friends

Extra English Practice

- To study

- To meet with my friends

To play games

- To get a drink in the cafe

- Other

What is the main purpose of the English Lounge, in your opinion?

- It is a place for students to complete homework assignments. It is an academic space.
- It is a place for students to practice everyday English. It is an informal study space.

- It is a place for students to relax and spend time with other students. It is a social space.

Here are some questions about the English Lounge with GTFS

Do you prepare topics or questions before going to lounge?
- Yes
- No
- Sometimes

In the 15-minute session, how many minutes do you speak?
- Less than one
- 4
- 1
- 2
- 5
More than 5

- 3

In the 15-minute session, how many minutes does the GTF speak?

- 1

- 2

- 3

- 4

- 5

- More than 5

Do you visit the same GTF often? Or do you visit a different GTF?

- Same GTF often

- Different GTF every week

- Different GTF every two weeks or more

What do you want to practice with GTFs?
- Speaking
- Listening
- Pronunciation
- Grammar

Do you think you get good practice with GTFs? Why or why not? 


\section{JALT2020}

COMMUNITIES OF
TEACHERS \& IEARNERS

What do you want to do most in lounge with GTFs?

- Learn about the GTF

- Learn about the GTFs culture

- Talk about common topics (hobbies, weekend plans, university life, etc.)

- Talk about difficult or challenging topics (politics, emotions, psychology, etc.)

- Play a game

- Listen to stories from the GTF

- Tell stories myself

- Talk with the GTF and my peers

\section{Final Thoughts}

What more would you like to see in English Plaza?

- More resources (study books, self-access study materials like audio and video lessons, etc.)

- More creative spaces (places to do art, a marker space, etc.)

- More social events (parties, dances, group meetings, etc.)

- More conversation opportunities (more GTF lounge times, conversation clubs, etc.)

- Other

After you finish your compulsory courses, do you think you will continue going to the English Lounge?

- Yes, but more times than I go now

- Yes, about the same amount I go now

- Yes, but fewer times than I go now No

What would make you want to come to English Plaza more often?

Why do you think you will not go to the English Lounge in the future?

\section{Appendix B}

\section{Teacher Survey}

The survey attached has been modified to fit the parameters of the journal. The first part of the teacher survey is similar to the student survey. Below are questions specific to teachers. If readers would like access to the full survey, please contact the authors.

\section{Lounge and Pedagogical Practices}

What do you do to prepare students for conversations in lounge? Please select all that apply.

- I have students select topics before they go to lounge

- I have students prepare questions to ask the GTF before they go to lounge

- I have students review their previous lounge experiences before they go to the next lounge

- I have students set conversational or language goals before they go to lounge

- I teach students specific conversational strategies to use before they go to lounge

- Nothing

- Other

How do you follow-up on student participation in lounge? Please select all that apply.

- Checking attendance (English Plaza Passport, Eventbrite Data, etc.)

- Collecting data on topics they discuss (via English Plaza Passport, Signature Sheet)

- Having students write summaries of their conversations in Plaza (To check comprehension and collect details about their engagement)

- Discussing their time in lounge one-on-one

- Having students discuss their time in lounge in small groups or with a partner

- Other

Do you allow students time in class to discuss learning strategies or conversation strategies they use in the English Lounge?
- Yes
- No
- Other 


\section{JALT2020}

COMMUNITIES OF
TEACHERS \& IEARNERS

If yes, what is the structure of these conversations?

If no, why don't you do this? Please select all that apply?

- No time due to curriculum demands

- I don't perceive any value in having them do this

- I don't understand the value in having them do this

- Students don't have the language ability to talk about this topic

- I wouldn't know how to structure the activity

- I wouldn't know how to assess the activity

Do you encourage students from your classes to go together as small groups or individually?

- I suggest they go with a friend.

- I suggest they do in a group of three

- I suggest they go with a friend or in a group of three

- I suggest they go alone

- I don't suggest anything on this matter 